Volume 11

Issue 3 Global Approaches to Atrocity

Prevention: Theory, Practice, and the State of

Article 11 the Field

$3-2018$

\title{
The Reduction of Mass Atrocity Crimes in East Asia: The Evolving Norms of ASEAN's Prevention Mechanisms
}

David A. Frank

University of Oregon

Follow this and additional works at: https://digitalcommons.usf.edu/gsp

\section{Recommended Citation}

Frank, David A. (2018) "The Reduction of Mass Atrocity Crimes in East Asia: The Evolving Norms of ASEAN's Prevention Mechanisms," Genocide Studies and Prevention: An International Journal: Vol. 11:

Iss. 3: 98-108.

DOI:

http://doi.org/10.5038/1911-9933.11.3.1503

Available at: https://digitalcommons.usf.edu/gsp/vol11/iss3/11

This Articles is brought to you for free and open access by the Open Access Journals at Digital Commons @ University of South Florida. It has been accepted for inclusion in Genocide Studies and Prevention: An International Journal by an authorized editor of Digital Commons @ University of South Florida. For more information, please contact digitalcommons@usf.edu. 


\section{The Reduction of Mass Atrocity Crimes in East Asia: The Evolving Norms of ASEAN's Prevention Mechanisms}

\section{Acknowledgements}

Based on a paper presented to the Carnegie Council for Ethics and International Affairs Global Ethics Fellows Fifth Annual Conference, New York, NY, October 2015. I would like to thank Edward Luck, Dana Luck, and Alexander Bellamy for the conversations that inspired this essay. 


\title{
The Reduction of Mass Atrocity Crimes in East Asia: The Evolving Norms of ASEAN's Prevention Mechanisms
}

\author{
David A. Frank \\ University of Oregon \\ Eugene, OR, USA
}

\begin{abstract}
Introduction $^{1}$
"East Asia's recent past is littered with examples of conscience shocking inhumanity against civilian populations," writes Alexander Bellamy. 2 "Indeed, for much of the Cold War, people in East Asia were arguably at greater risk of death by genocide and mass atrocities than anyone else in the world," Bellamy observes. ${ }^{3}$ He continues:

Almost unnoticed, however, the region has been transformed. There are fewer cases of genocide and mass atrocities in East Asia today than at any point in history for which we have reliable records. This change has coincided with, and been informed by, a quiet revolution in the region's understanding of the rights and responsibilities of sovereignty. ${ }^{4}$
\end{abstract}

This "quiet revolution" is due in part to an unfolding commitment to what Steven Pinker has called the global human rights revolution, which broke out in the wake of World War II and spread to the countries in East Asia. ${ }^{5}$

Pinker has assembled in his book, The Better Angels of Our Nature, compelling "big data," drawn from a host of sources, that since 1945 the world community has experienced a significant reduction in the number of genocides and mass atrocities. ${ }^{6}$ While it is a controversial thesis that seems to be defied by current events, including President Bashar al-Assad's barrel bombing of Syrian civilians and the rise of ISIS, Pinker has effectively answered his critics and has updated his argument. ${ }^{7}$ In comparative terms, "the world's civilians are several thousand times less likely to be targeted today than they were 70 years ago," argue Pinker and Mack. ${ }^{8}$ The development of norms by the global community that are then adopted by regional organizations like the Association of South East Asian Nations (ASEAN) ${ }^{9}$ help explain the success of the post-World War II human rights revolution.

The global community created the UN (1945), held 13 trials holding the Nazis responsible for crimes against humanity (1947-1948), and endorsed the Convention on the Prevention and Punishment of the Crime of Genocide (1948), and more recently, the Responsibility to Protect doctrine (2005). The doctrine, based on three pillars, makes it a responsibility for the member states of the United Nations to prevent genocide and mass atrocities that may result from interstate and

${ }^{1}$ This article is based on a paper presented to the Carnegie Council for Ethics and International Affairs Global Ethics Fellows Fifth Annual Conference, New York, NY, October 2015. I would like to thank Edward Luck, Dana Luck, and Alexander Bellamy for the conversations that inspired this essay.

${ }^{2}$ Alexander J. Bellamy, "The Other Asian Miracle? The Decline of Mass Atrocities in East Asia," Global Change, Peace E Security 26, no. 1 (2014), 1.

${ }^{3}$ Ibid.

${ }^{4}$ Ibid., 1; Timo Kivimäki, "East Asian Relative Peace and the ASEAN Way," International Relations of the Asia-Pacific 11, no. 1 (2010), 57-85; Benjamin E. Goldsmith, “A Liberal Peace in Asia?," Journal of Peace Research 44, no. 1 (2007), 5-27.

${ }^{5}$ Steven Pinker, The Better Angels of Our Nature: Why Violence Has Declined (New York: Viking, 2011). Pinker's thesis covers a 10,000 year period, not just to 1945 .

${ }^{6}$ Ibid.

${ }^{7}$ Steven Pinker, "Response to the Book Review Symposium: Steven Pinker, the Better Angels of Our Nature," Sociology 49, no. 4 (2015), 3-5.

${ }^{8}$ Steven Pinker and Andrew Mack, "Why the World Is Not Falling Apart," Slate Magazine, December 22, 2014, accessed December 30, 2017, http://www.slate.com/articles/news and politics/foreigners/2014/12/the world is not falling apart the trend lines reveal an increasingly peaceful.html.

${ }^{9}$ The Association of Southeast Asian Nations (ASEAN) has ten members: Brunei Darussalam, Myanmar/Burma, Cambodia, Indonesia, Laos, Malaysia, Philippines, Singapore, Thailand, and Vietnam. 
intrastate conflict. ${ }^{10}$ Luck and Luck correctly argue that R2P has been a success; it has been called one of the fastest-developing international norms in history. ${ }^{11}$ Beginning in 2005, the norms of R2P have inspired international activism, have been invoked in twenty-five UN Security Council resolutions, have been used to justify successful efforts to prevent or mitigate atrocity violence in Africa (Kenya, 2008; Burundi, 2008; Cote d'Ivoire, 2010; Libya, 2011), and have contributed to the reduction of mass atrocities in East Asia.

I suggest that the reduction of mass atrocity crimes in East Asia can be attributed to the global human rights revolution and ASEAN genocide and mass atrocities prevention norms and mechanisms that work to assimilate the global values of R2P with those of ASEAN member states. The "ASEAN way" serves as a positive model for other regional organizations. ${ }^{12}$ To be sure, the recent mass atrocities committed against the Rohingya civilians in Myanmar, a member of ASEAN, illustrate that the creation of shared human rights norms may be a necessary but not a sufficient condition for the prevention of human rights abuses. However, the horror visited upon the Rohingya stands out in relief against a relatively violence-free period in the region, and as a 2015 report issued by the Holocaust Museum indicated, there were many warning signs, including the violation of accepted regional and international norms of human rights, suggesting that the Rohingya would become targets of mass atrocities. ${ }^{13}$ The government of Myanmar has violated established international and ASEAN human rights norms; the issue now concerns the political will needed to enforce the norms.

Bellamy is careful to acknowledge that the acceptance of the R2P norm is but one of four factors in the reduction of mass atrocities in Southeast Asia:

The dramatic and sustained decline of genocide and mass atrocities in East Asia was not produced by any single factor, but by the combined effects of at least four important ones: a reduction in the deliberate targeting of civilians in war, growing incomes across the region, creeping democratization, and changing ideas about the nature of sovereignty and the responsibilities for protection. ${ }^{14}$

Three of these factors, Bellamy observes, are structural; the fourth is cultural and symbolic, a result of the incorporation of norms adapting the values of global human rights and R2P to those of East Asia. ${ }^{15}$ These structural forces have played powerful roles in the reduction of mass atrocities and in the creation of prevention mechanisms. Research has suggested as well that these structural factors alone, without the appropriate cultural and ideational norms, do not and cannot lead to reduction in mass atrocities. ${ }^{16}$ In the case of East Asia, it is clear that the establishment of human rights norms and the values codified in R2P have played a role in the reduction of atrocities. As Pinker, Bellamy, and others document, the structural factors that influence the outbreak or prevention of mass atrocities are framed by ideas, norms, and discourse. ${ }^{17}$ The post-World War II human rights revolution has, in Bellamy's words, altered the thinking in East Asian countries

\footnotetext{
${ }^{10}$ Alexander J. Bellamy, ed., The Responsibility to Protect: A Defense (Oxford: Oxford University Press, 2015).

${ }^{11}$ Edward C. Luck and Dana Luck, "The Individual Responsibility to Protect," in Reconstructing Atrocity Prevention, eds. Sheri P. Rosenberg, Tibi Galis, and Alex Zucker (New York: Cambridge University Press, 2015), 207-248.

${ }^{12}$ Mikio Oishi, "Can ASEAN Cope with 'Human Insecurity' in Southeast Asia? In Search of a New ASEAN Way," in Human Insecurities in Southeast Asia, Vol. 5, eds. Paul J. Carnegie, Victor T. King, and Zawawi Ibrahim (New York: Springer, 2016), 103-119.

${ }^{13}$ United States Holocaust Memorial Museum, They Want Us All To Go Away: Early Warning Signs of Genocide in Burma (Washington D.C.: United Holocaust Museum Press, 2015).

${ }^{14}$ Bellamy, The Responsibility to Protect, 19.

${ }^{15}$ Ibid., 1-2; Bellamy, The Other Asian Miracle?.

${ }^{16}$ Bellamy, The Other Asian Miracle?; Jennifer M. Welsh, "Norm Contestation and the Responsibility to Protect," Global Responsibility to Protect 5, no. 4 (2013), 365-396; Noële Crossley, Evaluating the Responsibility to Protect: Mass Atrocity Prevention as a Consolidating Norm in International Society (New York: Routledge, 2016).

${ }^{17}$ Pinker, The Better Angels of Our Nature; Alexander J. Bellamy, "Atrocity Prevention: From Promise to Practice in the Asia Pacific," Global Responsibility to Protect 8, no. 2-3 (2016), 180-199.
} 
about what constitutes legitimate conduct. These ideational shifts, which came in part from global transformations, and in part from within the region, were transmitted by the region's growing middle class and activist civil societies and changed the expectations about the proper relationship between governments and peoples. ${ }^{18}$

Scholars have corroborated Bellamy's conclusions: Okere, Aning, and Nelson find that the countries of ASEAN "have become increasingly involved in moving the [R2P] norm from rhetoric to practice." ${ }^{\prime 19}$ While there is a significant body of work that examines the three structural factors that play significant roles in the decline of genocide and mass atrocity in East Asia, I seek here to briefly explain how ASEAN's genocide and mass atrocity prevention mechanisms intended to foster changes in thinking and norms about human rights have contributed to the atrocity prevention mechanisms and how they are evolving.

ASEAN was formed in 1967 to promote economic development and regional stability and has contributed to the reduction in interstate war in the region. ${ }^{20}$ However, until the creation of the R2P doctrine, ASEAN countries did not concern themselves with the mass atrocities that have taken place within the borders of their member states until the advent of R2P. The Asia Pacific Centre for the Responsibility to Protect (APCR2P is "the most important norm entrepreneur and advocate for R2P in Southeast Asia..."). ${ }^{21}$ The Centre "has led efforts to socialize the region on the 2005 version of R2P" and seeks to embed the three pillars of R2P, including extension of the human rights imperative into the internal politics of ASEAN member countries. ${ }^{22}$ Launched in February 2008 with the help of Assistant Secretary-General of the United Nations Edward Luck and former Foreign Minister of Canada Lloyd Axworthy, the aspiration of the Centre, observes Noel Morada, one of the Centre's directors, is to build "domestic constituencies around" the R2P norm with its various programs. ${ }^{23}$

To build the R2P norm, the APCR2P uses a "bottom-up" approach through use of seminars and workshops at the local level in the Asia-Pacific region on R2P and offers scholars the opportunity to conduct policy-relevant, peer-reviewed academic research. The efforts of the Centre and the more general and gradual acceptance in the region of the responsibilities of the state to protect its citizens, and when it doesn't, the responsibility of outside bodies to assist or to intervene to protect human beings, irrespective of their geographical location, has borne some fruit in Southeast Asia. The consensus of the emerging literature suggests that if global norms of human rights are to find a place in ASEAN mass atrocity prevention mechanisms, they will need to be grafted onto those that currently rule in the region; they cannot be imposed. ${ }^{24}$

The first mission of the APCR2P is to offer R2P norm-building training, projects, activities, and workshops. Noel Morada, after conducting a series of interviews and workshops at different locations in the Asia-Pacific region in 2005 to determine what might be done to promote R2P norms, identified three best practices: translations of important UN and R2P materials into East Asian languages, development and inclusion of R2P materials in the curriculum of East Asian universities, and R2P workshops for government officials, military personnel, and important civilian groups. The legacy of the Centre's first R2P constituency-building workshop, hosted by the Centre in the Philippines on June 25-26, 2009, is of importance. The workshop brought representatives from

\footnotetext{
${ }^{18}$ Bellamy, The Responsibility to Protect, 14.

${ }^{19}$ Frank Okere, Kwesi Aning, and Susan Nelson, "Article 4(H) of the African Union Constitutive Act," in Africa and the Responsibility to Protect: Article 4(H) of the African Union Constitutive Act, eds. Dan Kuwali and Frans Viljoen (Abingdon: Routledge, 2013), 279.

${ }^{20}$ Kivimäki, East Asian Relative Peace, 57-58.

${ }^{21}$ David Capie, "The Responsibility to Protect Norm in Southeast Asia: Framing, Resistance and the Localization Myth," The Pacific Review 25, no. 1 (2012), 82.

${ }^{22}$ Ramesh Thakur, “The Responsibility to Protect at 15," International Affairs 92, no. 2 (2016), 430.

${ }^{23}$ Noel M. Morada, "ASEAN Responses to the Responsibility to Protect: Challenges, Opportunities and Constraints," in Responsibility to Protect: From Principle to Practice, eds. Julia Hoffmann, André Nollkaemper, and Isabelle Swerissen (Amsterdam: Amsterdam University Press, 2012), 242.

${ }^{24}$ Capie, The Responsibility to Protect Norm in Southeast Asia, 75-93.
} 
all of the important constituencies and focused on how the R2P norm could be promoted in the Philippines. Morada reports that the workshop played an important role in providing information on R2P to the Philippines' Department of Foreign Affairs, which in turn influenced the Philippines' taken on R2P during a meeting about the doctrine at the UN in July $2009 .{ }^{25}$

The second mission of the Centre is to promote research on R2P. The Centre has served as a publishing house for works of research and as a scholarly clearinghouse for R2P in the Asia-Pacific region. The APCR2P website hosts an "R2P Ideas in Brief" webpage. As a "resource hub," the webpage lists reports, podcasts, newsletters, and issue briefs outlining problems facing R2P. The Centre has published full reports. A review of the "Ideas in Brief," which lists five annual volumes of research summaries of major issues, reveals well-researched and written case studies of R2P as applied to human rights problems in the Asia-Pacific region. ${ }^{26}$ Individual scholars sponsored by the Centre have made significant scholarly contributions to our understanding of genocide and mass atrocity prevention mechanisms set forth by ASEAN. Two stand out as norm entrepreneurs: Noel Morada and Alexander J. Bellamy. Both have provided comprehensive treatments of efforts made by ASEAN member states to establish and develop the architecture for atrocity prevention.

Morada, in his 2006 article "R2P Roadmap in Southeast Asia: Challenges and Prospects," outlined a future of R2P in the Asia-Pacific region. ${ }^{27}$ Written one year after the doctrine was endorsed by the United Nations, Morada's contribution is prescient, as he accurately predicted both the obstacles to and the promise of implementing R2P in Southeast Asia. ASEAN member states, with their principle of noninterference, have successfully avoided interstate war, but the principle undercuts interference and interventions that might prevent mass atrocities committed by ASEAN member states against its citizens. ${ }^{28}$ Morada has led efforts to embed the values of R2P in the East Asian cultural context.

Bellamy is a prolific author, and he has emerged as an international authority on R2P. His articles in Ethics and International Affairs, reviewing R2P at five years (2010) and at ten years (2015), are major contributions to an understanding of R2P's perils and potential. Articles published in 2008 (on conflict prevention and the responsibility to protect), 2009 (on R2P in the Asia-Pacific region), three in 2011 (on R2P, the invasion of Libya, global politics, and international law), and his 2015 The Responsibility to Protect: A Defense (Oxford University Press) contribute to an understanding of R2P and the importance of norms and their creation, adaptation, and adoption. ${ }^{29}$ Morada and Bellamy provide important leadership and support for ASEAN member states to implant the norms of human rights and $\mathrm{R} 2 \mathrm{P}$ as mass atrocity prevention mechanisms.

\footnotetext{
${ }^{25}$ Morada, “ASEAN Responses," 243.

${ }^{26}$ See for example, Garima Mohan, "India and the Responsibility to Protect," R2P Ideas in Brief 4, no. 3 (2014), 1-9.

${ }^{27}$ Noel M. Morada, “R2P Roadmap in Southeast Asia: Challenges and Prospects," UNISCI discussion papers, no. 11 (2006), 59-70.

${ }^{28}$ Ibid.; Noel M. Morada, "Entrenching Responsibility to Protect in the Asia-Pacific," in The Globalization of World Politics: Case Studies from Australia, New Zealand and the Asia Pacific, eds. Charles Hawkesly and Nichole Georgeou (South Melbourne: Oxford University Press, 2014); Noel M. Morada, "Institutionalization of Regional Order: Between Norms and Balance of Power," in Regional Order in East Asia: ASEAN and Japan Perspectives, ed. Jun Tsunekawa (Tokyo: National Institute for Defense Studies, 2007); Noel M. Morada, "The Association of Southeast Asian Nations," in An Institutional Approach to the Responsibility to Protect, eds. Zyberi Gentian and Kevin T. Mason (Cambridge, UK: Cambridge University Press, 2013); Noel M. Morada, “The Responsibility to Protect: Why This Evolving Norm Matters and Is Here to Stay," in Debating the Endtimes of Human Rights: Activism and Institutions in a Neo-Westphalian World, eds. Doutje Lettinga and Lars van Troost (Amsterdam: The Strategic Studies Project, Amnesty International Netherlands, 2014).

${ }^{29}$ Alexander J. Bellamy, "Responsibility to Protect or Trojan Horse? The Crisis in Darfur and Humanitarian Intervention after Iraq," Ethics \& International Affairs 19, no. 2 (2005), 31-54; Alexander J. Bellamy, "Whither the Responsibility to Protect? Humanitarian Intervention and the 2005 World Summit," Ethics E International Affairs 20, no. 2 (2006), 143169; Alexander J. Bellamy and Sara E. Davies, "The Responsibility to Protect in the Asia-Pacific Region," Security Dialogue 40, no. 6 (2009), 547-574; Alexander J. Bellamy, Global Politics and the Responsibilty to Protect: From Words to Deeds (London and New York: Routledge, 2011); Alexander J. Bellamy, Sara Ellen Davies, and Luke Glanville, The Responsibility to Protect and International Law (Leiden and Boston: Martinus Nijhoff Publishers, 2011); Bellamy, The Other Asian Miracle?,1-19; Alexander J. Bellamy, “The Responsibility to Protect Turns Ten," Ethics \& International Affairs 29, no. 2 (2015), 161-185; Bellamy, The Responsibility to Protect.
} 
Seaman writes that ASEAN "provides one of the most interesting case studies in relation to R2P." ${ }^{30}$ Although Morada notes that the doctrine "remains a difficult norm to promote and gain acceptance in South-East Asia," some progress is evident. ${ }^{31}$ R2P seems to be "making significant inroads as a regional norm in the Asia-Pacific region" 32 and has "great promise as a norm developer for the principles of underpinning conflict prevention..." ${ }^{\prime 33}$ The literature suggests that at least four norms, with varying levels of acceptance, are in use or development by ASEAN member states.

\section{The ASEAN Way: The Norm of Collective Decision Making through Networked Civil Societies in South East Asia}

The formation of ASEAN in 1967 fostered diplomatic communication, promoted the creation of shared values among the ten-member states, and helped create a regional civil society. As Morada writes,

For almost 40 years, ASEAN has relied principally on norm-building and promotion to manage inter-state conflicts... Much of the pressure [to create norms] emanates from an increasingly networked civil society groups in Southeast Asia, which has undeniably become a moral force to contend with especially on humanitarian issues and concerns. In short, ASEAN states cannot just simply ignore the emergence of a regional civil society that now serves as the main avenue for promoting more people-oriented norms in ASEAN. ${ }^{34}$

ASEAN, according to James Waller's recent survey, "has demonstrated a constructive capacity to partner with existing institutions, mechanisms, and relevant government actors of the 10 countries within their organization to promote genocide prevention." ${ }^{35}$ After the end of the Cold War, ASEAN countries sought to create shared norms between 1997 and 2007, which then led community building between 2008 and $2015 .{ }^{36}$ To be sure, the progress toward shared norms has not been without setbacks, as ASEAN's collective decision making resists rapid implementation of new values. Rather, over time, the networked ASEAN civil societies work out through compromise and accommodation the tensions between global and local norms. ${ }^{37}$

Bellamy points to the numerous efforts made by his Centre and ASEAN member states to promote atrocity prevention. There are a "number of regional initiatives" under way to strengthen mass atrocity prevention norms, including the Asia Pacific Partnership for Atrocities Prevention. ${ }^{38}$ These initiatives build from the progress made to prevent mass atrocities in the region, doing so by recognizing that individual nations will need to assimilate global human rights values through dialogue and debate. ASEAN uses a consensus model of decision making, with all of its drawbacks and strengths. While it takes time to secure a consensus, a process Bellamy rightly calls "exasperating," the shared judgments that produce norms are "sustainable and considered legitimate." 39 The progress to establish norms against mass atrocity made through the networked

\footnotetext{
${ }^{30}$ Kate Seaman, "The Regionalization of the Responsibilty to Protect," in The Responsibility to Protect and the Third Pillar: Legitimacy and Operationalization, eds. Daniel Fiott and Joachim Koops (New York: Springer, 2014), 63.

${ }^{31}$ Morada, The Association of Southeast Asian Nations, 248.

${ }^{32}$ David Carment, Joe Landry, and Sean Winchester, “The Role of Regional Organizations: A Responsibility Gap?,” in The Oxford Handbook of the Responsibility to Protect, eds. Alexander J. Bellamy and Timothy Dunne (Oxford: Oxford University Press, 2016), 360.

${ }^{33}$ Alexander J. Bellamy and Timothy Dunne, The Oxford Handbook of the Responsibility to Protect (Oxford: Oxford University Press, 2016).

${ }^{34}$ Morada, R2P Roadmap in Southeast Asia, 64-65.

${ }^{35}$ James Waller, Confronting Evil: Engaging Our Responsibility to Prevent Genocide (Oxford: Oxford University Press, 2016), 196.

${ }^{36}$ Noel M. Morada, "Southeast Asian Regionalism, Norm Promotion and Capacity Building for Human Protection: An Overview," Global Responsibility to Protect 8, no. 2-3 (2016): 118-119.

${ }^{37}$ Sarah Teitt, "Asia Pacific and South Asia," in The Oxford Handbook of the Responsibility to Protect, eds. Alexander J. Bellamy and Timothy Dunne (Oxford: Oxford University Press, 2016), 380-381.

${ }^{38}$ Bellamy, Atrocity Prevention: From Promise to Practice, 187.

${ }^{39}$ Ibid., 189.
} 
civil societies of ASEAN member states has been, in Bellamy's judgment, "impressive." ${ }^{40}$ As a preventative mechanism, the collective decision making based on consensus is understood as the "ASEAN Way." ${ }^{11}$ ASEAN has, over time, assimilated some of the global human rights norms.

\section{The Norms of Global Human Rights}

Although Bellamy categorizes the decrease in the use of mass atrocities as a stratagem of war as a structural factor, he also acknowledges that the "principal reasons why states have moved away from employing mass atrocities as a tactic are both ideational and material in nature." ${ }^{42}$ The creation of international norms prohibiting genocide and mass atrocity after World War II, backed by the physical and moral force of the United Nations and the International Criminal Court (ICC), found their way into the value structures of ASEAN member states. These actions include an ongoing interrogation of norms that have been used to justify mass atrocity. Norms in the AsiaPacific region that were once viewed as "natural," such as the right of a nation to attack another or the right of a state to commit mass atrocities against its citizens, have been inverted. Since 2005, countries in the Asia-Pacific region have gradually come to view human rights as a responsibility of the sovereign state. Rather than framing relationship between global human rights and state sovereignty as an antinomy, the R2P doctrine has prompted ASEAN member states to define the protection of human rights as a responsibility of the state.

The R2P doctrine has encouraged sovereign states in the Asia-Pacific region to broaden the range of their responsibilities to include the prevention of mass atrocities. As such, ASEAN member states are attending to factors that spark atrocity crimes, including climate change, economic disparities, food security, and others. Teitt identifies two efforts made by ASEAN member states to broaden the focus of mass atrocity prevention. ${ }^{43}$ First, the Japanese are working to broaden the definition of human security to include social and economic inequalities, health disparities, hunger, and other problems. Second, ASEAN member states are seeking to implement policies that confront poverty and economic inequality as mass atrocity prevention measures. The "narrow but deep approach to implementing R2P," Teitt writes, "which recognizes a broader development assistance agenda is part of the global effort to end atrocities, resonates both with human security concepts originating in the Asia Pacific and the structural capacity-building agenda advocated by the states in the region." 44

The consensus of the scholarship on ASEAN human rights norms and mass atrocity prevention mechanisms suggests that both are the result of slow and incremental modifications of local norms through consensus-building decision-making procedures. International and regional organizations, including ASEAN, are in constant dialogue through the offices of the United Nations and institutions like APCR2P. The goal is to assimilate the universal values of human rights into the norms of ASEAN countries. Indonesia and the Philippines, for example, endorsed both the nonintervention policy favored by ASEAN member states and the third pillar of R2P that called for intervention into the affairs of a sovereign state when that state had failed to protect the human rights of its citizens. The "consensus decision-making and evolutionary institutional change" in use by the United Nations "appears to have increased comfort among Asia Pacific states" with the R2P implementation agenda. ${ }^{45}$ However, ASEAN member states have not fully worked through the tension between the doctrine of nonintervention, which has decreased interstate mass atrocities, and R2P in its call for humanitarian intervention by outside forces when a state has failed in its responsibility to protect its citizens. A norm bridging the two is forming.

\footnotetext{
${ }^{40}$ Ibid., 190.

${ }^{41}$ Ibid., 117. Morada, Southeast Asian Regionalism.

${ }^{42}$ Bellamy, The Other Asian Miracle?, 8.

${ }^{0}$ Teitt, Asia Pacific and South Asia.

${ }^{44}$ Ibid., 379.

${ }^{45}$ Ibid., 380 .
} 
An Evolving Norm Nesting the Principle of Noninterference and the Responsibility to Protect within the Sovereign State

ASEAN's founding documents (1967), the Zone of Peace, Freedom and Neutrality Declaration of 1971, and the 1976 Treaty of Amity and Cooperation and Article Two of the ASEAN Charter (2007) commit ASEAN to the principle of noninterference by external parties in the sovereign affairs of member states. The significant decline in the number of mass atrocities due to armed conflict between states in the region since the end of the Cold War can be traced to this principle. ${ }^{46}$ Indeed, "scholars are relatively unanimous in agreeing that during the first decades of ASEAN, the principle [of non-interference] managed to translate into reality." ${ }^{47}$ As a result, "there has been no interstate conflict involving casualties between two ASEAN members, despite the fact that some ASEAN members have been traditional enemies since before joining the organization. This is the case also in East Asia: inter-state war has almost disappeared after 1979, and especially after 1987." 48 Paradoxically, the principle also protected and shielded states that committed mass atrocities against its own citizens. ASEAN has resisted contesting human rights abuses conducted by its member states against its citizens. ${ }^{49}$

The application of the principle of noninterference by ASEAN "has been extremely strict and has presented one of the major obstacles for ASEAN human rights bodies to interpret their mandates and their functions effectively since their inception. ${ }^{\prime 50}$ ASEAN was faced with the choice of either rejecting or accepting R2P's principle that interference and intervention in the affairs of an ASEAN member state is justified if the government is committing human rights abuses against its citizens. Rather than framing the choice as a binary, ASEAN is attempting to bridge the two through an act of creative accommodation and dissociation. ${ }^{51}$

ASEAN is on a trajectory that is slowly, with its ponderous, consensus-based decision making, aligning and assimilating the principle of noninterference with the three pillars of R2P. ${ }^{52}$ The networked international and regional civil societies have insisted that the ASEAN principle of noninterference "evolve in a way that reflects a degree of receptivity to principles associated with R2P... Thus, many Southeast Asian states are moving away from the traditional notion of sovereignty and towards accepting a localised variant of sovereignty as responsibility." ${ }^{33}$ This act of assimilation and dissociation is not simply a crude importation of global human rights norms or a continuation of local practices with a symbolic nod to R2P. Rather, ASEAN has engaged in the negotiation and creative adaptations producing new norms "that alters both the new norm (R2P) and those more established norms (non-interference)." 54

The ASEAN dissociation and creative reframing of the principle of non-interference and those of R2P has broadened the definition of ASEAN state sovereignty to include the responsibility to safeguard the human rights of its citizens. Bellamy and Drummond highlight two illustrations of this new formulation in action: ASEAN's response to Cyclone Nargis, which caused 138,000 causalities in Myanmar in 2008, and the positions taken by the region's governments during the 2009 UN General Assembly debate on R2P. Both illustrations demonstrate how ASEAN honored the principle of noninterference, while justifying intervention to secure the human rights of individuals within member states as acts of assisting sovereign states to protect their citizens.

\footnotetext{
${ }^{46}$ Bellamy, The Other Asian Miracle?.

${ }^{47}$ Kivimäki, East Asian Relative Peace, 64.

${ }^{48}$ Ibid., 73.

${ }^{49}$ Alexander J. Bellamy and Catherine Drummond, "The Responsibility to Protect in Southeast Asia: Between NonInterference and Sovereignty as Responsibility," The Pacific Review 24, no. 2 (2011), 185-186.

${ }^{50}$ Sriprapha Petcharamesree, "ASEAN Human Rights Regime and Mainstreaming the Responsibility to Protect: Challenges and Prospects," Global Responsibility to Protect 8, no. 2-3 (2016), 138.

${ }^{51}$ Bellamy and Drummond, The Responsibility to Protect in Southeast Asia. On the role of creative accomodation and dissociation as a means of transcending binaries, see Chaïm Perelman and Lucie Olbrechts-Tyteca, eds. The New Rhetoric, a Treatise on Argumentation (Notre Dame: University of Notre Dame Press, 1971), 411-459.

${ }^{52}$ Bellamy and Drummond, The Responsibility to Protect in Southeast Asia.

${ }^{53}$ Ibid., 196.

${ }^{54}$ Ibid., 197.
} 
Bellamy, in his 2016 survey concludes, "significant normative progress has been made in building a regional consensus around the principle of the responsibility to protect." ${ }^{15} \mathrm{In}$ light of this progress, ASEAN member states are now creating the norms necessary to prevent mass atrocity.

\section{The Norm of Mass Atrocity Prevention}

While atrocity crimes have decreased in Southeast Asia, there is a need to strengthen existing and build new structures designed to prevent future outbreaks. The research suggests that mass atrocity prevention is best done at the national level. Scholars and government officials are seeking to build from the ASEAN's successes in reducing the frequency of mass atrocities to develop an ASEANinflected R2P. Toward this end, a major effort is under way to fully mainstream R2P in Southeast Asia. Government reports and scholars have offered recommendations that if implemented would help create national architectures for ASEAN member states designed to prevent mass atrocities. ${ }^{56}$ Among the many recommendations, three are at the top of the agenda:

A. The need to continue promoting R2P and adapting it to the values and norms in the region. To accomplish this end, R2P should be "properly contextualized in ASEAN's language." 57 An effort should be made to suggest that ASEAN regional norms, values, and principles are embedded in the Responsibility to Protect and are not alien to it." ${ }^{58}$

B. A dedicated effort to strengthen and develop mass atrocity early warning systems. Social science has identified the precursors to mass atrocity. ASEAN member states seek to develop the tools needed to alert policymakers and the general public to conditions, speech, and behavior that foretell mass atrocity. There is a need for networks that join the ten ASEAN member states for the purpose of gathering and analyzing information on human rights violations. At present, ASEAN countries need to devote resources to the development of national architectures designed to prevent atrocity crimes.

C. The constructive management of diversity and deep pluralism. Atrocity crimes are often the result of identity-based conflict. Government reports and scholarship highlight the need for ASEAN countries to create cultural space and government institutions for people of multiple and overlapping identities. Legal protections for minorities or those who do not adhere to the majority's religion or lifestyle are necessary to inoculate against atrocity crimes. Conflict management systems, including conciliation, mediation, and arbitration, should play major roles in atrocity prevention.

\section{Conclusion}

The member states of ASEAN have successfully reduced the number of wars and as a result, the frequency of mass atrocities since the formation of the association in 1967. Scholars have identified structural factors (reduction of mass atrocities as a weapon of war, rising incomes, and the spread of democracy) and the norms framing them as explanations. The norms in play determine the influence of the structural factors on the frequency of mass atrocities. The effectiveness of these norms can be debated. Kassim argues, "R2P has only enjoyed lip service in Southeast Asia." ${ }^{59}$ However, Kassim agrees with Bellamy and others that the doctrine is gaining acceptance as the norm is debated and discussed by ASEAN member states. ${ }^{60}$ ASEAN member states have adopted norms of collective decision making and global human rights and are integrating global human rights into regional and national value systems. Although there are serious environmental and political issues facing ASEAN, the association can draw from its history of success to develop new norms that equip member states with the tools needed to prevent atrocity crimes. ASEAN stands as

${ }_{55}$ Bellamy, Atrocity Prevention: From Promise to Practice, 199.

${ }^{56}$ High Level Advisory Panel, Mainstreaming the Responsibility to Protect in Southeast Asia (New York: United Nations, 2014); Petcharamesree, ASEAN Human Rights Regime; Bellamy and Drummond, The Responsibility to Protect in Southeast Asia.

${ }^{57}$ Panel, Mainstreaming the Responsibility, 333.

${ }^{58} \mathrm{Ibid}$.

${ }^{59}$ Yang Razali Kassim, "ASEAN and R2P," in The Geopolitics of Intervention (New York: Springer, 2014), 54.

${ }^{60}$ Bellamy and Dunne, The Oxford Handbook of the Responsibility to Protect. 
a model in its success at decreasing atrocity crimes, and the norms it has set forth and is developing can offer lessons to other regional organizations. Future studies of successful norm creation should include the roles played by the ASEAN Commission on the Promotion and the Protection of the Rights of Women and Children (ACWC), the ASEAN Intergovernmental Commission on Human Rights (AICHR), the R2P focal points adopted by Australia, Cambodia, and Timor-Leste, and the UN's “Human Rights Up Front" initiative on the formation of ASEAN's human rights norms.

\section{Bibliography}

Bellamy, Alexander J. "Atrocity Prevention: From Promise to Practice in the Asia Pacific." Global Responsibility to Protect 8, no. 2-3 (2016): 180-199. https://doi.org/10.1163/1875984X-00803006 . Global Politics and the Responsibilty to Protect: From Words to Deeds. London and New York: Routledge, 2011.

. "Responsibility to Protect or Trojan Horse? The Crisis in Darfur and Humanitarian Intervention after Iraq." Ethics \& International Affairs 19, no. 2 (2005): 31-54. https://doi. org/10.1111/j.1747-7093.2005.tb00499.x

---------. "The Other Asian Miracle? The Decline of Mass Atrocities in East Asia." Global Change, Peace \& Security 26, no. 1 (2014): 1-19. https://doi.org/10.1080/14781158.2014.865600

. The Responsibility to Protect: A Defense. Oxford: Oxford University Press, 2015.

. "The Responsibility to Protect Turns Ten." Ethics \& International Affairs 29, no. 2 (2015): 161-185. https://doi.org/10.1017/S0892679415000052

. "Whither the Responsibility to Protect? Humanitarian Intervention and the 2005 World Summit." Ethics \& International Affairs 20, no. 2 (2006): 143-169. https://doi.org/10.1111/ j.1747-7093.2006.00012.x

-------- and Sara E. Davies. "The Responsibility to Protect in the Asia-Pacific Region." Security Dialogue 40, no. 6 (2009): 547-574. https://doi.org/10.1177/0967010609349907

--------, Sara E. Davies, and Luke Glanville. The Responsibility to Protect and International Law. Leiden and Boston: Martinus Nijhoff Publishers, 2011.

and Catherine Drummond. "The Responsibility to Protect in Southeast Asia: Between Non-Interference and Sovereignty as Responsibility." The Pacific Review 24, no. 2 (2011): 179-200. https://doi.org/10.1080/09512748.2011.560958

-------- and Timothy Dunne. The Oxford Handbook of the Responsibility to Protect. Oxford: Oxford University Press, 2016. https://doi.org/10.1093/oxfordhb/9780198753841.001.0001

Capie, David. "The Responsibility to Protect Norm in Southeast Asia: Framing, Resistance and the Localization Myth." The Pacific Review 25, no. 1 (2012): 75-93. https://doi.org/10.1080/09512 $\underline{748.2011 .632967}$

Carment, David, Landry Joe, and Winchester, Sean. "The Role of Regional Organizations: A Responsibility Gap?" In The Oxford Handbook of the Responsibility to Protect, edited by Timothy Dunne and Alexander J. Bellamy, 335-357. Oxford: Oxford University Press, 2016.

Crossley, Noële. Evaluating the Responsibility to Protect: Mass Atrocity Prevention as a Consolidating Norm in International Society. New York: Routledge, 2016.

Goldsmith, Benjamin E. "A Liberal Peace in Asia?" Journal of Peace Research 44, no. 1 (2007): 5-27. https://doi.org/10.1177/0022343307072427

High Level Advisory Panel. "Mainstreaming the Responsibility to Protect in Southeast Asia." New York: United Nations, 2014.

Kassim, Yang Razali. "ASEAN and R2P." In The Geopolitics of Intervention, 57-71. Singapore: Springer, 2014. https://doi.org/10.1007/978-981-4585-48-4 5

Kivimäki, Timo. "East Asian Relative Peace and the ASEAN Way." International Relations of the AsiaPacific 11 (2010): 57-85. https://doi.org/10.1093/irap/lcq016

Luck, Edward C. and Dana Luck. "The Individual Responsibility to Protect." In Reconstructing Atrocity Prevention, edited by Sheri P. Rosenberg, Tibi Galis, and Alex Zucker, 207-248. New York: Cambridge University Press, 2015. https://doi.org/10.1017/CBO9781316154632.012

Mohan, Garima. "India and the Responsibility to Protect." R2P Ideas in Brief 4, no. 3 (2014): 1-9. 
Morada, Noel M. "ASEAN Responses to the Responsibility to Protect: Challenges, Opportunities and Constraints." In Responsibility to Protect: From Principle to Practice, edited by Julia Hoffmann, Andre Nollkaemper, and Isabelle Swerissen, 237-246. Amsterdam: Amsterdam University Press, 2012.

. "Entrenching Responsibility to Protect in the Asia-Pacific." In The Globalization of World Politics: Case Studies from Australia, New Zealand \& the Asia Pacific, edited by Charles Hawksley and Nichole Georgeou, 23-26. South Melbourne: Oxford University Press, 2014. . "Institutionalization of Regional Order: Between Norms and Balance of Power." In Regional Order in East Asia: ASEAN and Japan Perspectives, edited by Jun Tsunekawa, 31-53. Nids Joint Research Series, no. 1. Tokyo: National Institute for Defense Studies, 2007.

"R2P Roadmap in Southeast Asia: Challenges and Prospects." UNISCI discussion papers, no. 11 (2006): 59-70.

"Southeast Asian Regionalism, Norm Promotion and Capacity Building for Human Protection: An Overview." Global Responsibility to Protect 8, no. 2-3 (2016): 111-132. https://doi.org/10.1163/1875984X-00803003

-------. "The Association of Southeast Asian Nations." In An Institutional Approach to the Responsibility to Protect, edited by Zyberi Gentian and Kevin T. Mason, 247-267. Cambridge, UK: Cambridge University Press, 2013.

. "The Responsibility to Protect: Why This Evolving Norm Matters and Is Here to Stay." In Debating the Endtimes of Human Rights: Activism and Institutions in a Neo-Westphalian World, edited by Doutje Lettinga and Lars van Troost, 77-84. Amsterdam: The Strategic Studies Project, Changing Perspectives on Human Rights, Amnesty International Netherlands, 2014.

Oishi, Mikio. "Can ASEAN Cope with 'Human Insecurity' in Southeast Asia? In Search of a New ASEAN Way." In Human Insecurities in Southeast Asia, edited by Paul J. Carnegie, Victor T. King, and Ibrahim Zawawi, 103-119. New York: Springer, 2016. https://doi.org/10.1007/978981-10-2245-6 7

Okere, Frank, Kwesi Aning, and Susan Nelson. "Article 4(H) of the African Union Constitutive Act." In Africa and the Responsibility to Protect: Article 4(H) of the African Union Constitutive Act, edited by Dan Kuwali and Frans Viljoen, 278-287. Abingdon: Routledge, 2013.

Perelman, Chaïm and Lucie Olbrechts-Tyteca. The New Rhetoric, a Treatise on Argumentation. Notre Dame: University of Notre Dame Press, 1971.

Petcharamesree, Sriprapha. "ASEAN Human Rights Regime and Mainstreaming the Responsibility to Protect: Challenges and Prospects." Global Responsibility to Protect 8, no. 2-3 (2016): 133157. https://doi.org/10.1163/1875984X-00803004

Pinker, Steven. The Better Angels of Our Nature: Why Violence Has Declined. New York: Viking, 2011.

--------. "Response to the Book Review Symposium: Steven Pinker, the Better Angels of Our Nature." Sociology 49, no. 4 (2015): 3-8. Accessed Janaury 23, 2018. https://doi. org/10.1177/0038038514556797

-------- and Andrew Mack. "Why the World Is Not Falling Apart." Slate Magazine, December 22, 2014. Accessed December 30, 2017. http://www.slate.com/articles/news and politics/ foreigners/2014/12/the world is not falling apart the trend lines reveal an increasingly peaceful.html.

Seaman, Kate. "The Regionalization of the Responsibilty to Protect." In The Responsibility to Protect and the Third Pillar: Legitimacy and Operationalization, edited by Daniel Fiott and Joachim Alexander Koops, 58-77. New York: Springer, 2014. https://doi. org/10.1057/9781137364401.0010

Teitt, Sarah. "Asia Pacific and South Asia." In The Oxford Handbook of the Responsibility to Protect, edited by Alexander J. Bellamy and Timothy Dunne, 373-390. Oxford: Oxford University Press, 2016.

Thakur, Ramesh. “The Responsibility to Protect at 15." International Affairs 92, no. 2 (2016): 415-434. https://doi.org/10.1111/1468-2346.12557

Waller, James. Confronting Evil: Engaging Our Responsibility to Prevent Genocide. Oxford: Oxford University Press, 2016. 
Welsh, Jennifer M. "Norm Contestation and the Responsibility to Protect." Global Responsibility to Protect 5, no. 4 (2013): 365-396. https://doi.org/10.1163/1875984X-00504002 